\title{
An Overview of Coping with Stress Among Mothers Accompanying Their Children Through Online Learning During COVID-19 Pandemic
}

\author{
Euodia Yolanda ${ }^{1}$ Widya Risnawaty ${ }^{1 *}$
}

\author{
${ }^{1}$ Faculty of Psychology, Tarumanagara University, DKI Jakarta, Grogol Petamburan 11440, Indonesia \\ *Corresponding author.E-mail: widyar@fpsi.untar.ac.id
}

\begin{abstract}
COVID-19 virus that has plagued the entire world has made major changes in various aspects of life. The rapid spread of this virus has forced Indonesian government to implement Large-Scale Social Restrictions (in Indonesian known as "Pembatasan Sosial Berskala Besar") in order to suppress the spread of the virus, which requires various activities to be done through online media, including schools and education system. Currently, schools implement an online learning system that is accessed from their respective homes. However, it turns out that the current system created stress among parents who accompany their children in online learning. The purpose of this study is to describe coping with stress among parents who accompany their children through online learning during COVID-19 pandemic. The method used in this research is in-depth interviews so the information obtained will be rich and more detailed. Participants used in this study are housewives and working moms who are working from home, aged 18-40 years and are accompanying their children who are taking online learning. Also, this study used participants who do not use the services of household assistants. The results shown that the causes of stress in housewives and working moms are slightly different, specifically working moms have difficulty in managing their time. Therefore, parents use both emotion-focused coping strategies and problem-focused coping strategies as an effort to return to a balanced state, where the emotionfocused coping strategies are more frequently used than problem-focused coping strategies.
\end{abstract}

\section{Keywords: Online learning, coping with stress, coping strategy, parental stress, stressors}

\section{INTRODUCTION}

In early 2020, almost all parts of the world were infected with a new virus known as COVID-19 (Corona Virus Disease-19). Based on data from WHO, there are 216 countries that have experienced the COVID-19 pandemic, including Indonesia[1]. This requires the government to implement self-quarantine in accordance with a health protocol called Large-Scale Social Restrictions (PSBB)[2]. The formation of this PSBB requires people to remain at home[3]. People who work outside must work from home[4], and students are forced to take online-based learning [5], [6].

These things cause sudden changes in habits in daily life, where these changes become obstacles for the community because they have to adjust to unexpected circumstances. [7] - [10]. These changes put parents in a position at risk of experiencing stress[8]. Changing the education system to online learning is also a problem for parents and makes parents stressed, especially for parents who have children who are at the school level[11]. One study shows that as many as $35 \%$ of parents struggle with childcare responsibilities[12]. Problems resulting from this change become stressful experiences for parents who have to balance office work, homework, and child care.[9], [13], [14]. Arranging time for work and children is very difficult for parents, especially for families who do not have household assistants[14]. The phenomenon of closing schools globally contributes to the stress of parents because parents are left alone to handle their children's education[14].

The stress experienced by parents can have a negative impact on children's emotions [15] and more enabling parents to engage in child abuse and neglect [8], [9]. Previous research has found that rates of violence against children increase as schools close[16]. Violence in children can have a negative physical and psychological impact on children, both in the short and long term[17] - [19]. Online learning itself also has a special effect on children physically, such as being less physically active, having more screen time, sleeping and eating irregularly.[20], [21] and psychologically like, frustration and boredom [21].

\subsection{Research Aims}

This article aims to provide information on the description of stress and coping by parents. This study will explore the stressors that arise that cause stress for parents when 
accompanying their children to undergo online learning during the COVID-19 pandemic, as well as how parents cope with these stressors using coping strategies. This knowledge can be useful for increasing parental awareness of stress so that they can determine coping strategies that suit them.

\subsection{Paper Structure}

This paper is composed of 5 parts. The first part is an introduction, the second part describes the basic theory used in this study, namely an explanation of the coping strategy. Section 3 contains research methods. Then, the research findings and discussion are in section 4. Finally, section 5 contains conclusions and suggestions for further research.

\section{BACKGROUND}

\subsection{Coping}

Lazarus and Folkman [22], [23]classify coping strategies into two types. First, problem-focused coping which leads to individual efforts to overcome the problems experienced, in this case it means that the effort made is to modify existing stressors. Second, emotion-focused coping, which refers to reducing the emotions associated with the received stressor, which means that this effort is made to regulate or regulate the emotional state caused by the stressor.

Definition 1. (coping with stress) Coping is an adaptation process carried out to reduce the impact of stressful events and to help restore and strengthen stability in the family unit [24].

\section{METHODS}

This type of research is qualitative with a phenomenological approach. The data collection technique used was in-depth interviews to help researchers get information-rich and detailed answers from the participants[25]. The sampling technique used was purposive sampling, in which a nonrandom sample was selected to represent cases from a very specific and difficult to reach population.[26]. The characteristics of the participants in this study were as follows: (a) early adult women (18-40 years) who have at least one child, who is currently in grades 1-3 elementary school and is undergoing online learning, (b) participants accompanying their children who undergo online learning, (c) participants are mothers who work from home during the COVID-19 pandemic and full-time housewives, and (d) participants do not use the services of household assistants at home. The data that has been collected will be processed into an orthographic transcript by writing down all the conversations of the interviewers and participants[27]. After that, the data will be coded based on the predetermined themes and sub themes[26], then the coding results will be entered in the subject analysis table.

The first step in research preparation is to find subjects who meet the criteria for the participants that have been determined. Subjects searches are carried out by contacting family and relatives who have characteristics as determined by WhatsApp. Researchers consulted about the phenomena felt by parents in Indonesia during this pandemic. After conducting the consultation, researchers found four people who were likely to be participants. Then, researchers asked for participants' permission informally on the availability of sources to become potential participants in this study as well as informing participants about the timing of data collection.

Interviews were conducted via WhatsApp video calls and voice calls with the consideration of participants' lack of knowledge in technology. Interviews were conducted 2 time to 2 participants and 1 time to 2 participants. The first interview is used to build a rapport and ask questions according to the interview guidelines. The second interview is used to ask questions that have not been clearly answered by the participants, and to confirm to the participants that the answers they gave are the correct answers.

Table 1 Participant demographic data

\begin{tabular}{ccccc}
\hline Categories & P1 & P2 & P3 & P4 \\
\hline Age & 33 & 30 & 40 & 40 \\
last education & High school & $\begin{array}{c}\text { High } \\
\text { school }\end{array}$ & S1 & S1 \\
Profession & $\begin{array}{c}\text { Housewife and own an } \\
\text { online shop }\end{array}$ & Housewife & $\begin{array}{c}\text { Housewife, online bakery, and } \\
\text { own expedition }\end{array}$ & Housewife \\
$\begin{array}{c}\text { Number of } \\
\text { children }\end{array}$ & 2 persons & 1 person & 3 people & 3 people \\
Children's age & 8 and 4 years & 6 years & 8, 7, and 5 years & $\begin{array}{c}\text { 16, 12, and 7 } \\
\text { years }\end{array}$ \\
\hline
\end{tabular}




\section{FINDINGS AND DISCUSSIONS}

Stressors that can be resolved with an emotion-focused coping strategy are immature online learning systems, slow internet networks, unstable children's mood when studying, and noisy atmosphere during the day. Meanwhile, problemfocused coping is used on stressors such as lack of knowledge of subject matter, difficulty in managing time, and child development problems such as poor fine motor skills that cause children to be lazy to write.

Parents use emotion-focused coping by watching movies, listening to songs, reading books, shopping and beautifying themselves, cooking new recipes, learning foreign languages, deepening religion, and creating a positive mindset in order to be more accepting of the current situation. Meanwhile, problem-focused coping is used in ways, including searching for information on the internet or books, also opening Google Translate when there are foreign language lessons such as English and Mandarin, asking people who are more proficient in these subjects to teach children, and attend seminars. to broaden horizons. Working mom makes a priority scale to organize time so that all work can be handled one by one. In addition, parents teach independence to children such as eating alone, bathing alone, tidying up rooms, and wash the dishes. This is useful for reducing household chores that must be done by mothers.

Table 2 The use of coping strategies on stressors

\begin{tabular}{|c|c|c|}
\hline $\begin{array}{l}\text { Coping } \\
\text { strategies }\end{array}$ & Stressor & The way it is done \\
\hline $\begin{array}{c}\text { Emotion- } \\
\text { focused coping }\end{array}$ & $\begin{array}{l}\text { - Unclear online learning system } \\
\text { - Slow internet network } \\
\text { - The child's mood is unstable } \\
\text { - when undergoing online learning } \\
\text { - Noisy atmosphere during the day }\end{array}$ & $\begin{array}{ll}\text { - } & \text { Watching movies } \\
\text { - } & \text { Listening to music } \\
\text { - } & \text { Reading book } \\
\text { - } & \text { Online Shopping } \\
\text { - } & \text { Having eyelash extension } \\
\text { - } & \text { Cooking } \\
\text { - } & \text { Learn a foreign language } \\
\text { - } & \text { Deepening religion } \\
\text { - } & \text { Create a mindset to accept the situation } \\
\text { - } & \text { Trying to enjoy the present situation by not } \\
& \text { thinking too much about negative things }\end{array}$ \\
\hline $\begin{array}{c}\text { Problem- } \\
\text { focused coping }\end{array}$ & $\begin{array}{l}\text { - Lack of parental knowledge on } \\
\text { subject matter } \\
\text { - Trouble timing }\end{array}$ & $\begin{array}{l}\text { - Searching for information on the internet or } \\
\text { books } \\
\text { - } \text { Asking someone more skilled to teach } \\
\text { - } \text { Make a priority scale } \\
\text { - Teaches independence to children }\end{array}$ \\
\hline & - Motor problems in children & - Attend online seminars \\
\hline
\end{tabular}

The online learning system becomes a difficulty for parents when the school where their child studies does not apply video conferencing to become a medium for online learning. This causes no interaction between teachers and students, and no further explanation for parents. In fact, Sun and Chen[28]said that effective online learning requires well-designed study classes, where there is interaction between teacher and student. This makes parents feel afraid of wrong ways to teach their children.

"Sometimes we as parents explain it differently from the teacher"

"I'm afraid that what is taught is not the same as what the teacher teaches the way ... the way"

In addition, the lack of parental knowledge in subject matter can be seen from the educational background of the parents. A higher educational background can increase the likelihood of parents being involved in their child's education [29]. The stress caused by the lack of mastery of material also occurs due to differences in the level of material difficulty in the past and the present.

Communication problems with teachers, where the teacher sometimes informs the exam schedule suddenly becomes an obstacle for parents. This is related to the partnership between teachers and parents. In fact, partnerships between teachers and parents have been shown to reduce stress on parents[30]. This partnership can be formed effectively with the involvement of parents in children's academics[31]. Anxiety about COVID-19 can be a cause of stress[13], [32]. In this study, parents stopped their children from tutoring because they were worried that their children would be infected with a virus, so that the assignments that could be shared with the tutor had to be handled by the parents themselves so that the parents would have difficulties. This also relates to experiences in teaching children, which can 
be a cause of stress for parents. Participants who always submitted their children's academics to tutors and never taught their children before the pandemic felt very difficult and stressed at this time. It is different with participants who were used to teaching their own children from before the pandemic, they did not find it difficult because they were experienced.

On the other hand, working moms have a special stressor, namely difficulties in managing time. The duties of parents increase when they have to do work and household affairs while accompanying children in academics. This a lot of work will take up the parents' time[8] which will make it difficult for parents to manage time [13].

There are different types of stressors between parents who only have one child and parents who have more than one child. Parents who have a child can focus more on accompanying their child in undergoing online learning, so that the stressors they feel come from online learning alone. Meanwhile, parents who have more than one child certainly have more tasks in taking care of their children, which take up more time for parents, so that the stressors that arise do not only come from online learning, such as difficulties in managing time.

With the stressors mentioned above, parents become stressed so they try to return to a balanced state by coping. Parents use emotion-focused coping more often than problem-focused coping because they have limited resources, for example, social support providers such as tutoring centers that have to close due to the pandemic, and inadequate mastery of the material they have.

This study found differences in the use of coping strategies among parents with high school and undergraduate education. Parents with high school education tend to use emotion-focused coping more often and parents with an undergraduate degree tend to use problem-focused coping strategies. This happens because parents with high school education have not been able to determine a suitable coping strategy to do, while those with an undergraduate degree are more focused in determining good strategies and solutions to their problems. This discussion proves that parents with high school education need more effort to stabilize their emotions.

The choice of coping strategy is also related to age. Previous research by Sharma[33]proved that emotional intelligence is positively related to age where emotional intelligence develops and increases with age and experience. In addition, personality also determines the choice of coping strategies[34] and its effectiveness [35]. That is, a coping strategy can be useful for someone, but not necessarily effective for other people with different personalities[36].

\section{CONCLUSIONS}

Based on the results of the study, it can be concluded that all participants used both types of coping strategies, where emotion-focused coping is more frequent than problemfocused coping. Emotion-focused coping is used as an effort to reduce tension or is distracting and is used on stressors that cannot be resolved such as unclear online learning systems and lack of information from teachers. Meanwhile, problem-focused coping is relatively more effective to solve problems and is used for stressors that can be solved such as lack of parental knowledge and problems in managing time.

Further research can examine learning from the teacher's point of view in order to find out the needs and difficulties from the teacher's side. In addition, further researchers can evaluate online learning systems so that they can provide suggestions for the government and schools. Further researchers can also deepen the study of age, personality, and emotional intelligence in relation to coping with stress.

\section{REFERENCES}

[1] World Health Organization, "Corona virus disease (covid-19) pandemic," World Health Organization, 2020. https://www.who.int/es/emergencies/diseases/ novel-coronavirus-2019 (accessed Sep. 06, 2020).

[2] N. R. Yunus and A. Rezki, "The Policy on Lock Down Implementation in Anticipation of the Spread of the Corona Virus Covid-19," SALAM J. Sos. and Syar-i Culture, vol. 7, no. 3, 2020, doi: 10.15408 / sjsbs.v7i3. 15083.

[3] Zaharah, G. I. Kirilova, and A. Windarti, "The impact of the corona virus outbreak on teaching and learning activities in Indonesia," Regards, J. Sos. and Syar'i Culture, vol. 7, no. 3, pp. 269-282, 2020, doi: 10.15408 / sjsbs.v7i3.15104.

[4] R. A. Umasugi, "Psbb in Jakarta is valid until April 20 and can be extended," Compass, Apr. 07, 2020.

[5] H. Pajarianto, A. Kadir, G. Nursaqinah, P. Sari, and S. Februarianti, "Study from home in the middle of the COVID-19 pandemic: Analysis of religiosity, teacher, and parents support against academic stress," Talent Dev. Excell., vol. 12, no. 2, pp. 1791-1807, 2020.

[6] H. Yulia, "Online learning to prevent the spread of the corona virus pandemic in Indonesia," ETERNAL (English Teach. Journal), vol. 11, no. 1, pp. 48-56, 2020, doi: 10.26877 / eternal.v11i1.6068.

[7] C. Brom, J. Lukavský, D. Greger, T. Hannemann, J. Straková, and R. Švaříček, "Mandatory home education during the COVID-19 lockdown in the Czech Republic: A rapid survey of 1st-9th graders' parents, "Front. Educ., vol. 5, no. March, pp. 1-8, 2020, doi: 10.3389 / feduc.2020.00103.

[8] A. K. Griffith, "Parental burnout and child maltreatment during the COVID-19 pandemic," J. Fam. Violence, 2020, doi: 10.1007 / s10896-020-00172-2. 
[9] K. L Humphreys, M. T. Myint, and C. H. Zeanah, "Increased risk for family violence during the COVID19 pandemic," Pediatrics, vol. 146, no. 1, 2020, doi: 10.1542 / peds.2020-0982.

[10] L. J. Riegler, S. P. Raj, E. L Moscato, M. E. Narad, A. Kincaid, and SL Wade, "Pilot trial of a telepsychotherapy parenting skills intervention for veteran families: Implications for managing parenting stress during COVID-19," J. Psychother. Integr., vol. 30, no. 2, pp. 290-303, 2020, doi: 10.1037 / int0000220.

[11] M. Wu et al., "Mental health status of students' parents during COVID-19 pandemic and its influence factors," Gen. Psychiatry, vol. 33, no. 4, pp. 1-9, 2020, doi: 10.1136 / gpsych-2020-100250.

[12] K. Parker, J. M. Horowitz, and A. Brown, "About half of lower-income americans report household job or wage loss due to covid-19," Pew Research Center, 2020. https://www.pewsocialtrends.org/2020/04/21/abouthalf-of-lower-income-americans-report-household-jobor-wage-loss-due-to-covid-19 / (Accessed Sep. 08, 2020).

[13] S. M. Brown, JR Doom, S. Lechuga-Pena, SE Watamura, and T. Koppels, "Stress and parenting during the global COVID-19 pandemic," Child Abuse Negl., pp. 1-14, 2020, doi: 10.1016 / j.chiabu.2020.104699.

[14] M. Spinelli, F. Lionetti, A. Setti, and M. Fasolo, "Parenting Stress During the COVID-19 Outbreak: Socioeconomic and Environmental Risk Factors and Implications for Children Emotion Regulation," Fam. Process, no. September, 2020, doi: 10.1111 / famp. 12601.

[15] L. Dalton, E. Rapa, and A. Stein, "Protecting the psychological health of children through effective communication about COVID-19," Lancet Child Adolesc. Heal., vol. 4, no. 5, pp. 346-347, 2020, doi: 10.1016 / S2352-4642 (20) 30097-3.

[16] L. Cluver et al. " "Parenting in a time of COVID-19," Lancet, vol. 395, no. 4, p. 64, 2020, doi: 10.1016 / S0140-6736 (20) 30736-4.

[17] S. K. Brooks et al., "The psychological impact of quarantine and how to reduce it: a rapid review of the evidence," Lancet, pp. 1-9, 2020, doi: 10.1016 / S01406736 (20) 30460-8.

[18] B. L Fortson, J. Klevens, MT Merrick, LK Gilbert, and SP Alexander, Preventing child abuse and neglect: A technical package for policy, norm, and programmatic activities. National Center for Injury Prevention and
Control, Centers for Disease Control and Prevention, 2016.

[19] M. M. Haj-Yahia, S. Sokar, N. Hassan-Abbas, and M. Malka, "The relationship between exposure to family violence in childhood and post-traumatic stress symptoms in young adulthood: The mediating role of social support," Child Abus. Negl., vol. 92, pp. 126-138, 2019, doi: 10.1016 / j.chiabu.2019.03.023.

[20] N. Carroll et al., "The impact of COVID-19 on health behavior, stress, financial and food security among middle to high income canadian families with young children," Nutrients, vol. 12, no. 8, pp. 1-14, 2020, doi: 10.3390 / nu12082352.

[21] G. Wang, Y. Zhang, J. Zhao, J. Zhang, and F. Jiang, "Mitigate the effects of home confinement on children during the COVID-19 outbreak," Lancet, vol. 395, no. 10228, pp. 945-947, 2020, doi: 10.1016 / S0140-6736 (20) $30547-X$

[22] Lazarus and S. Folkman Hospital, Stress, appraisal, and coping. New York: Springer Publishing Company, Inc., 1984

[23] R. S. Lazarus and S. Folkman, "Transactional theory and research on emotions and coping," Eur. J. Press., 1987, doi: 10.1002 / per.2410010304.

[24] J. W. Peer, "Coping strategies," in The Wiley Blackwell Encyclopedia of Family Studies, 1st ed., John Wiley \& Sons, Inc., 2016.

[25] J. W. Creswell and JD Creswell, Research design: Qualitative, quantitative, and mixed methods approaches, 5th ed. Michigan: SAGE Publication, Inc., 2017.

[26] W. L Neuman, Social Research Methods: Qualitative and Quantitative Approaches, 7th ed. Essex: Pearson Education Limited, 2014.

[27] D. Howitt, Introduction to qualitative research methods in psychology, 3rd ed. London: Pearson Education Limited, 2016.

[28] A. Sun and X. Chen, "Online education and its effective practice: A research review," J. Inf. Technol. Educ. Res., vol. 15, no. 2016, pp. 157-190, 2016, doi: 10.28945 / 3502 .

[29] A. Kainuwa, N. Binti, and M. Yusuf, "Influence of Socio-Economic and Educational Background of Parents on their Children's Education in Nigeria," Int. J. Sci. Res. Publ., vol. 3, no. 10, pp. 2250-3153, 2013, [Online]. Available: www.ijsrp.org. 
[30] E. Rouse and D. O'Brien, "Mutuality and reciprocity in parent-teacher relationships: Understanding the nature of partnerships in early childhood education and care provision," Australas. J. Early Child., vol. 42, no. 2, pp. 45-52, 2017, doi: 10.23965 / AJEC.42.2.06.

[31] J. L Epstein et al., School, family, and community partnerships: your handbook for action, 3rd ed. California: Corwin Press, 2009.

[32] A. H. Khan, MS Sultana, S. Hossain, MT Hasan, HU Ahmed, and MT Sikder, "The impact of COVID-19 pandemic on mental health \& wellbeing among homequarantined Bangladeshi students: A cross-sectional pilot study," J. Affect. Disord., vol. 277, pp. 121-128, 2020, doi: 10.1016 / j.jad.2020.07.135.

[33] D. Sharma, "Impact of Age on Emotional Intelligence and Its Components," Int. J. Res. Innov. Soc. Sci., vol. I, no. I, pp. 2454-6186, 2017, [Online]. Available: www.ijriss.org.

[34] L. D. Malone, "Individual differences and stress reactions as predictors of performance in pilot trainees," 2010.

[35] P. Afshar, H., Roohafza, HR, Keshteli, AH, Mazaheri, M., Feizi, A., \& Adibi, "The association of personality traits and coping styles according to stress level," J. Res. Med. Sci., vol. 20, no. 4, pp. 353-358, 2015, [Online]. Available: https://www.ncbi.nlm.nih. gov/pmc/articles/PMC4468450/\#!po=80.7692.

[36] A. DeLongis and S. Holtzman, "Coping in context: The role of stress, social support, and personality in coping," J. Press., vol. 73, no. 6, pp. 1633-1656, 2005, doi: $10.1111 /$ j.1467-6494.2005.00361.x. 